\title{
Compound-Complex Criminal Statutes and the Constitution: Demanding Unanimity as to Predicate Acts
}

\author{
Eric S. Miller
}

In his first judicial act, Daniel, who would become one of the Hebrew Bible's most respected judges, saved an innocent woman from a death sentence.' Susanna, wife of the wealthy and respected Joakim, went to her garden to bathe. In the garden, two lecherous elders trapped her alone and demanded that she have sex with them. If she refused, they threatened to accuse her publicly of having sex with a man other than her husband, a crime whose punishment was death. Susanna did refuse, and the next day the elders accused her of adultery, telling the judges that they saw a young man lying with her in her garden. The judges believed the elders and sentenced Susanna to death.

As Susanna was being led to her execution, Daniel cried out, "Are you such fools, O Israelites! To condemn a woman of Israel without ... clear evidence?"2 Questioning the elders separately, Daniel asked each, "[U]nder which tree did you see them together?"3 One elder answered, "Under a mastic tree"; the other answered, "Under an oak." On the basis of this lack of agreement, Susanna was freed. "Thus was innocent blood spared that day. . . . And from that day onward Daniel was greatly esteemed by the people."

In modern criminal procedure terminology, Daniel was confronted with a problem of verdict specificity. To Daniel, a determination that the accused was guilty of the crime charged was not enough. Instead, he demanded "clear evidence" of how the crime was committed. Without such evidence, Daniel said, the judges were "passing unjust sentences" and "condemning the innocent."7

1. The following story is taken from Daniel 13:1-64 (New American Bible).

2. Id at $13: 48$.

3. Id. at $13: 54,: 58$.

4. Id. at 13:55.

5. Id. at 13:59.

6. Id. at $13: 62$ to $: 64$.

7. Id at 13:53. 
Like Daniel, the United States Constitution demands a certain level of verdict specificity. The Sixth Amendment requires that convicting jurors in federal criminal trials be unanimous not solely as to the ultimate question of guilt or innocence, but also as to the principal factual elements of the crime charged. However, the recent advent of the compound-complex criminal statute, with its novel definitions of crime and its elements, has strained the limits of criminal procedure and effectively taken the right to a unanimous verdict away from a large and growing class of federal criminal defendants.

Compound-complex criminal statutes generally target large-scale criminal activity by requiring that a defendant have engaged in a "pattern" or "series" of criminal conduct. The "pattern" or "series" must consist, in turn, of a specific number of predicate acts defined elsewhere in the criminal code. The most difficult challenge raised by compound-complex statutes is one of verdict specificity. In order to convict a defendant of a compound-complex crime, must a jury unanimously agree upon exactly which acts the defendant committed? Or need the jury only unanimously agree that the defendant committed a certain number of such acts, without specifically agreeing on their identity? This question has split the circuit courts, making it particularly appropriate for review under the Constitution.

The Constitution does speak to questions of jury unanimity and verdict specificity. The Sixth Amendment requires unanimity as to the principal factual elements underlying a specified offense. ${ }^{8}$ In addition, the Due Process Clause of the Fifth Amendment constrains Congress' ability to define the elements of a criminal offense. ${ }^{9}$ Unfortunately, courts have been unable to construct from these constitutional rules an analytical framework through which to evaluate verdict specificity problems in compound-complex criminal statutes. Nearly every court addressing the question of jury unanimity as to predicate acts has analyzed it solely in light of the Sixth Amendment's guarantee of unanimity as to the principal elements of an offense. Sixth Amendment analysis, however, does little more than frame the debate; it does not address the central question of what constitutes a principal element. The due process constraints on defining criminal activity, while proposing an answer to that question, were only recently articulated by the Supreme Court in the context of a first-degree

8. See, e.g., United States v. Ferris, 719 F.2d 1405, 1407 (9th Cir. 1983). This level of specificity is not, of course, mandated by the language of the Sixth Amendment itself, which states, "In all criminal prosecutions, the accused shall enjoy the right to a speedy and public trial, by an impartial jury of the State and district wherein the crime shall have been committed . . ." U.S. CONST. amend. VI; see also infra notes 33-37 and accompanying text.

9. See Schad v. Arizona, 501 U.S. 624, 632-33 (1991). The Fifth Amendment reads, "No person shall be ... deprived of life, liberty, or property, without due process of law . ..."U.S. CONST. amend. V; see also infra part II.B. 
murder statute; $;^{10}$ to date, only one court has analyzed compound-complex predicate acts in light of these constraints."

Most courts considering the issue under the Sixth Amendment have concluded that the Constitution does not require a federal jury to agree unanimously upon the identity of the specific predicate acts underlying a conviction for a compound-complex crime. Using the Continuing Criminal Enterprise Statute (CCE) as a case study, this Note argues that the Fifth Amendment's due process requirements demand that juries unanimously agree upon the specific predicate offenses necessary for a compound-complex conviction. On a functional level, this constitutional prescription requires judges to issue specific unanimity instructions to juries whenever the prosecution has presented evidence of more than the requisite number of predicate acts. In addition, the use of special interrogatories would give meaning to this constitutional protection without destroying the additional protection a general verdict affords criminal defendants.

Part I of this Note introduces compound-complex crimes, the problem of patchwork verdicts, and the special concerns posed by their intersection. Part $\Pi$ discusses the constitutional constraints imposed upon judges, juries, and Congress by the Fifth and Sixth Amendments and examines the ways in which these constraints differ and the manner in which courts have confused them. This Note then proposes a framework through which the two constraints work together to demand unanimity as to the elements of a crime, yet allow juror divergence as to mere alternate means of fulfilling the elements of a crime.

Part III reviews how the courts and commentators have applied Fifth and Sixth Amendment constraints to the predicate acts required by the CCE statute. This Note then applies the constitutional framework articulated in Part II to CCE predicate acts and concludes that, together, the Fifth and Sixth Amendments demand that juries unanimously agree upon the specific predicate acts necessary for compound-complex convictions.

Finally, Part IV outlines the procedural mechanisms necessary to implement the constitutional unanimity requirement as to predicate acts. This Note concludes that the Sixth Amendment requires that judges issue specific unanimity instructions to juries whenever the prosecution presents evidence of more than the number of predicate acts required for conviction. In addition, the right to jury unanimity as to predicate acts is best protected by the use of special interrogatories in particularly complicated compound-complex criminal cases.

10. Schad, 501 U.S. at 632-33.

11. See United States v. Anderson, 39 F.3d 331 (D.C. Cir. 1994); infra text accompanying notes $101-04$. 


\section{COMPOUND-COMPLEX CRIMES AND PATCHWORK VERDICTS}

Over the last twenty-five years, Congress has enacted a series of compound-complex criminal statutes in order to battle group and organizational crime in new, more effective ways. These statutes differ from traditional substantive criminal statutes in several respects. Most important, they require proof of a number of predicate offenses in order to sustain a conviction. These predicate offenses, and the compound nature of the proof they entail, pose difficult questions of jury unanimity and verdict specificity and greatly enhance the risk of "patchwork" guilty verdicts.

\section{A. Compound-Complex Crimes}

Beginning in 1970, Congress enacted a series of laws designed to deter and punish large-scale group and organizational crime. The Racketeering Influenced and Corrupt Organizations Act (RICO) ${ }^{12}$ is aimed at organized crime of all varieties. The CCE statute ${ }^{13}$ targets drug kingpins. The Gambling Business Statute ${ }^{14}$ proscribes large-scale and ongoing gambling activities. Finally, the Continuing Financial Crimes Enterprise statute (CFCE) ${ }^{15}$ subjects group financial crime to specific federal prosecution. While each of these statutes deals with traditional forms of criminal behavior, none of them is a traditional criminal statute. Instead, these federal laws are compound-complex criminal statutes. ${ }^{16}$

Compound-complex criminal statutes target subject-specific group and organizational crime through a number of novel mechanisms. Most require proof of participation of a minimum number of individuals in the proscribed activity. For instance, the CCE statute requires that the defendant supervise or manage five or more people. ${ }^{17}$ In addition, compound-complex statutes punish offenders with very severe sentences; the minimum prison term for a defendant

12. 18 U.S.C. $\$ \S 1961-1968$ (1988). RICO was enacted as part of the Organized Crime Control Act of 1970, Pub. L. No. $91-452,84$ Stat. 922.

13. 21 U.S.C. $\$ 848$ (1988 \& Supp. III 1991). The CCE was enacted as part of the Comprehensive Drug Abuse Prevention and Control Act of 1970, Pub. L. No. 91-513, 84 Stat. 1236.

14. 18 U.S.C. $\S 1955$ (1988). The compound-complex definition of an illegal gambling business was adopted as part of the Organized Crime Control Act of 1970, 84 Stat. at 937.

15. 18 U.S.C. $\$ 225$ (Supp. V 1993). Enacted in 1990, the CFCE is the most recent of the compoundcomplex criminal statutes.

16. While compound-complex statutes originated at the federal level, they have been copied by the states as well. However, this Note deals only with the federal statutes.

17. 21 U.S.C. $\S 848(b)(2)(A)$. The CFCE requires that the defendant supervise at least four persons acting in concert. 18 U.S.C. \& 225(b). Likewise, the Gambling Business Statute requires that the defendant supervise five or more persons. Id. $\S 1955($ b)(1)(ii). RICO contains no parallel requirement and can be violated by an individual acting alone. However, most RICO prosecutions charge that the defendant worked with others to conduct or participate in the affairs of an enterprise through a pattern of racketeering activity in violation of 18 U.S.C. $\$ 1963$ (c). NORMAN ABRAMS \& SARA SUN BEALE, FEDERAL CRIMINAL LAW AND ITS ENFORCEMENT 571 (2d ed. 1993). 
convicted of supervising a continuing criminal enterprise is twenty years, and the maximum is life. ${ }^{18}$

The defining characteristic of all compound-complex statutes is that they proscribe participation in a "pattern" or "series" of criminal conduct. The "pattern" or "series," in turn, consists of a specific number of violations of other criminal statutes. These violations are commonly termed "predicate offenses" or "predicate acts."

One of the specific elements of a CCE violation is that the defendant commit a federal drug offense as part of a specifically defined "continuing series" of violations of federal narcotics laws. ${ }^{19}$ The continuing series element, then, requires proof of predicate offenses. In fleshing out this requirement, the federal courts of appeals have defined a continuing series as consisting of at least three of the offenses enumerated in the statute. ${ }^{20}$ Any commission of the multitude of federal narcotics felonies contained in subchapters I and II of Chapter 13, Title 21 of the United States Code may be counted as one of the three predicate offenses. ${ }^{21}$ This group of felonies from which the predicates may be drawn is huge and diverse, encompassing drug crimes from simple possession to the import, export, and sale of large quantities of controlled substances. ${ }^{22}$ The other federal compound-complex criminal statutes contain requirements similar to the CCE's continuing series

18. 21 U.S.C. \& 848(a). RICO generally carries a maximum punishment of 20 years in pnson; it also allows life imprisonment if one of the predicate acts upon which the conviction is based carries a maximum penalty of life. 18 U.S.C. $\S 1963$ (a). CFCE mandates a minimum of 10 years and a maximum of life in prison. Id. $\S 225(\mathrm{a})$. The Gambling Business Statute carries the least severe penalties. prescribing a maximum penalty of five years imprisonment. Id. $\S 1955(a)$.

19. 21 U.S.C. \$ 848 reads:

(a) Penalties; forfeitures

Any person who engages in a continuing criminal enterprise shall be sentenced to a $\mathrm{tcm}$ of imprisonment which may not be less than 20 years and which may be up to life imprisonment. to a fine not to exceed ... $\$ 2,000,000 \ldots$

...

(c) "Continuing Criminal Enterprise" defined

For purposes of subsection (a) of this section, a person is engaged in a continuing crimunal enterprise if-

(1) he violates any provision of this subchapter or subchapter Il of this chapter the punishment for which is a felony, and

(2) such violation is a part of a continuing series of violations of this subchapter or subchapter II of this chapter-

(A) which are undertaken by such person in concen with five or more other persons with respect to whom such person occupies a position of organizer, a supervisory position, or any other position of management ....

20. See United States v. Hemandez-Escarsega, 886 F.2d 1560 (9th Cir. 1989), cert. denied. 497 U.S. 1003 (1990); United States v. Young, 745 F.2d 733, 747 (2d Cir. 1984) (collecting cases), cert. denied sub nom. Myres v. United States, 470 U.S. 1084 (1985); United States v. Valenzuela, 596 F.2d 1361. 1367 (9th Cir.), cert. denied, 444 U.S. 865 (1979). But see United States v. Baker, 905 F.2d 1100 (7th Cir.) (seeming to require only two predicate offenses to constitute continuing series), cen. denied sub nom. Manns v. United States, 498 U.S. 905 (1990).

21. 21 U.S.C. $\$ 848(c)(2)$.

22. The prohibited narcotics-related felonies are described in 21 U.S.C. $\$ \$ 841$ (a), $842(a)$, and 960 (a) (1988), and include all illegal drug-related activity. 
and allow the predicate offenses to be drawn from equally wide ranges of federal and state substantive crimes. ${ }^{23}$

\section{B. Patchwork Verdicts}

The compound nature of the proof necessary to convict under compoundcomplex criminal statutes raises serious questions of jury unanimity and verdict specificity. In particular, must the jury agree unanimously on the identity of the two or three predicate acts that constitute the pattern or continuing series? Or need the jury only be unanimous in concluding that three violations occurred? For example, in order to prove the continuing series element of a $\mathrm{CCE}$ violation, the prosecution may present evidence of four federal drug crimes, labeled $A, B, C$, and $D$, respectively. Six of the jurors may be convinced beyond a reasonable doubt that the defendant committed acts $A, B$, and $C$. The other six jurors may be convinced beyond a reasonable doubt that the defendant committed acts $B, C$, and $D$. Thus, the jury unanimously agrees only that the defendant committed two predicate offenses, $B$ and $C$. However, if the jury is instructed that they need only agree unanimously that any three predicate acts were committed, they will vote to convict because each of the twelve jurors is convinced that the defendant committed three predicate offenses. Such a guilty verdict is commonly called a "patchwork verdict" because it can only result by piecing together the jurors' different conceptions of the predicate acts that satisfy the continuing series element of the offense.

Patchwork verdicts also arise outside the context of compound-complex crimes. Often the prosecutor will charge, in a single count, a number of discrete acts, any one of which would constitute a violation of the statute under which the defendant is charged. ${ }^{24}$ In other cases, the prosecutor will charge the defendant under a statute that delineates several distinct mentes reae or actus rei through which the statute could be violated. ${ }^{25}$ In both of these

23. RICO requires that defendants engage in a "pattern of racketeering activity" 18 U.S.C. \$ 1962(a)-(c) (1988), which, in tum, must consist of "at least two acts of racketeering activity." Id. \$ 196I(5). RICO defines "racketeering activity" through reference to nine major categories of state crime and 35 different federal offenses. Id. § 1961(1); see also ABRAMS \& BEALE, supra note 17, at 451 (discussing RICO's incorporation of state and federal laws). One of the federal statutes included in the RICO definition of "racketeering activity" is the Travel Act, 18 U.S.C. $§ 1952$ (1988), which itself incorporates various state and federal crimes.

The CFCE requires that a defendant engage in a "series of violations" of enumerated federal financial crimes. Id. $\S 225$ (b) (Supp. V 1993). Similarly, the Gambling Business Statute defines illegal gambling by incorporating all state and local gambling crimes. Id. § 1955(b)(1)(i) (1988).

24. See, e.g., United States v. Duncan, 850 F.2d 1104, 1111 (6th Cir. 1988); United States v. Beros, 833 F.2d 455, 462 (3d Cir. 1987); United States v. Ferris, 719 F.2d 1405, 1407 (9th Cir. 1983).

25. See, e.g., Schad v. Arizona, 501 U.S. 624 (1991) (defendant charged under Arizona first-degree murder statute proscribing both premeditated and felony murder); United States v. Sanderson, 966 F.2d 184, 187 (6th Cir. 1992) (defendant charged under 18 U.S.C. \$ 666(a)(1)(A) (1988 \& Supp. III 1991), which permits prosecution of person who "embezzles, steals, obtains by fraud or otherwise without authority knowingly converts" govemment property); United States v. Gipson, 553 F.2d 453 (5th Cir. 1977) (defendant convicted under 18 U.S.C. $\$ 2313$ (1976), which permits prosecution of anyone who "reccives, 
situations, a jury could convict a defendant under the statute without unanimously agreeing as to exactly how the statute was violated. ${ }^{26}$

Compound-complex crimes present special problems of patchwork verdicts. By definition, compound-complex crimes require proof of a compound nature; proof of more than one actus reus and mens rea is required for conviction. Therefore, each time the prosecution presents evidence of more than the requisite number of predicate acts, the possibility for a patchwork verdict exists. $^{27}$

This problem is exacerbated by the approach the government commonly takes to prosecuting compound-complex crimes. Because the government need not charge or convict the defendant for each separate predicate offense, ${ }^{28}$ prosecutors engage in a scattershot approach to prosecuting compound-complex crimes, presenting evidence of as many predicate acts as possible with the hope of convincing the jury that the defendant committed at least the requisite number. Thus, it is common practice to present evidence of many more than the number of predicate acts needed to fulfill the pattern or series requirement. ${ }^{29}$ As the number of possible predicate offenses increases, so does the number of combinations of offenses justifying a conviction under the statute. For instance, if a prosecutor presents evidence of seven predicate offenses in order to prove the requisite three predicates under the $C C E$, the jury is faced with thirty-five unique combinations of three predicate acts that would support a conviction. ${ }^{30}$ If the jury is not told that it must agree

conceals, stores, barters, sells or disposes of any motor vehicle or aircraft . . knowing the same to have been stolen").

26. In a less troublesome form of patchwork verdict, a jury might unanimously agree on exactly what a defendant did, but each juror could reach his or her conclusion by relying upon different witnesses or other evidence. Hayden J. Trubith, Paichwork Verdicts, Different-Jurors Verdicts, and American Jury Theory: Whether Verdicts Are Invalidated by Juror Disagreement on Issues. 36 OkLA. L REV. 473, 474 (1983).

27. If, however, the prosecution presents evidence of only the requisite number of predicate acts, the danger of a patchwork verdict does not exist. For example, if the prosecution presents evidence of three federal narcotics felonies as suppor for a CCE conviction. the jury could not convict without unanimously agreeing on the identity of the three acts that constitute the continuing scries.

28. United States v. Young, 745 F.2d 733, 747 (2d Cir. 1984), cert. dented sub nom. Myres v. United States, 470 U.S. 1084 (1985).

29. See, e.g., United States v. Herrera, 23 F.3d 74, 74 (4th Cir. 1994) (govemment presented "abundant" evidence of predicate acts); United States v. LeMaux, 994 F.2d 684, 685-87 (9th Cir. 1993) (government presented evidence of seven predicate acts in suppon of CCE convicuon): United States $v$ Kramer, 955 F.2d 479, 482-83 (7th Cir.) (government presented evidence of al least seven predicate acts in support of CCE conviction), cert. denied, 113 S. CL. 595 (1992); United States v. Canıno, 949 F.2d 928. 932 (7th Cir. 1991) (government presented evidence of five predicale acts in support of CCE convietion). cert. denied, 112 S. Ct. 1940 (1992); United States v. Hernandez-Escarsega, 886 F.2d 1560. 1572 (9th Cir 1989) (govemment presented evidence of 11 predicate acts in support of CCE convicuon), cert. dented, 497 U.S. 1003 (1990); United States v. Echeverri. 854 F.2d 638. 642 (3d Cir. 1988) (govemment offered evidence of "a plethora" of predicate acts in support of CCE conviction).

30. The number of different combinations of eligible predicate acts is represented by the equation:

$$
\frac{n !}{(n-k) ! k !}
$$

where " $n$ " equals the number of predicates of which evidence was presented and " $k$ " equals the number of predicates needed to constitute the series or pattem. This equation is termed the binomial coeffictent for 
unanimously on exactly which acts support a conviction, it is possible, if not probable, that each juror will convict upon a different conception of the predicate acts committed.

In addition to the sheer number of predicate acts presented to juries in compound-complex trials, the variety of crimes eligible as predicates is astounding. Offenses eligible as predicates under the $\mathrm{CCE}$ range from simple possession to the manufacture and import of controlled substances. ${ }^{31}$ RICO predicates encompass nine major categories of state law ranging from murder to bribery, and thirty-five different federal offenses varying from wire fraud to trafficking in "white slaves." ${ }^{\text {"Th }}$ The broad range of crimes eligible as predicate acts under compound-complex criminal statutes makes possible a scenario in which jurors voting to convict have widely disparate views as to both the type and the severity of the "pattern" or "continuing series" in which the defendant engaged.

\section{CONSTITUTIONAL CONSTRAINTS ON JUROR UNANIMITY AND THE DEFINITION OF CRIMINAL CONDUCT}

Courts have had tremendous difficulty analyzing the problem of patchwork verdicts both within and without the context of compound-complex crimes. The Constitution, however, does constrain the actions of judges, juries, and Congress in ways that offer a solution to the problem of patchwork verdicts. The Sixth Amendment demands jury unanimity as to the principal factual elements of an offense, but begs the central question of what, exactly, constitutes a principal element. The Due Process Clause of the Fifth Amendment, on the other hand, addresses this question by requiring Congress to define certain courses of conduct as principal factual elements of an offense, rather than as mere alternative means of fulfilling an element of the offense. Utilizing these two constraints, this Part constructs a framework in which to analyze verdict specificity problems. Properly understood, Fifth Amendment due process constraints work to distinguish between facts upon which the Sixth Amendment demands unanimity and those upon which it does not.

$\mathrm{k}$ out of $\mathrm{n}$.

31. 21 U.S.C. $\$ \S 841$ (a), 842(a), 960(a) (1988). For example, in United States v. Smith, No. 94-1387, 1994 U.S. App. LEXIS 33252, at *1 (6th Cir. Nov. 22, 1994), the defendant was convicted of supervising a CCE. The eligible predicates included conspiracy to import heroin, conspiracy to possess with intent to distribute heroin, possession with intent to distribute heroin, and aiding and abetting these acts.

32. 18 U.S.C. \& 1961(1) (1988). 


\section{A. Sixth Amendment Constraints on Jury Unanimity}

The Constitution does not mention unanimous jury verdicts. ${ }^{33}$ Nonetheless, the Sixth Amendment has long been interpreted to require that jury verdicts in federal criminal trials be unanimous. ${ }^{34}$ The more difficult question, left unanswered by the Court for years, is the level of factual specificity demanded of a unanimous guilty verdict. Clearly, the Constitution requires more than a simple unanimous determination that the defendant has committed some crime. ${ }^{35}$ On the other hand, it does not require unanimity as to the insignificant details of a crime. ${ }^{36}$ In an attempt to strike the balance

33. Johnson v. Louisiana, 406 U.S. 356, 381 (1972) (Douglas, J.. dissenting).

34. Id. at 369 (Powell, J., concurring) ("In an unbroken line of cases reaching back into the late 1800 's, the Justices of this Court have recognized, virtually without dissent, that unanimity is one of the indispensable features of federal jury trial."). Powell cited the following cases: Andres v. United Suates. 333 U.S. 740, 748-49 (1948) (Sixth Amendment demands unanimity in federal criminal case); Patton $v$. United States, 281 U.S. 276, 288-90 (1930) (same); Hawaii v. Mankichi. 190 U.S. 197, 211-12 (1903) (same); Maxwell v. Dow, 176 U.S. 581, 586 (1900) (same): Thompson v. Utah, 170 U.S. 343. 355 (1898) (same). More recent cases have also adhered to this interpretation. United States v. Canino, 949 F.2d 928 . 946 n.5 (7th Cir. 1991) (same), cert. denied, 112 S. Ct. 1940 (1992); United States v. Smedes, 760 F.2d 109, 111 (6th Cir. 1985) (same); Sincox v. United States. 571 F.2d 876. 878 (5th Cir. 1978) (same): United States v. Gipson, 553 F.2d 453, 456 (5th Cir. 1977) (same).

Despite this long line of cases, some courts and commentators have mistakenly concluded that the unanimity rule has been deconstitutionalized and is now guaranteed only by Federal Rule of Criminal Procedure 31(a), which states, "The verdict shall be unanimous." FED. R. CRIM. P. 31(a). For instance, one scholar noted, "[U]nanimous verdicts remain the norm for criminal trials, but not as a matter of constitutional principle." Trubitt, supre note 26. at 507. The court of appeals in Sincox. 571 F.2d at 878. found it necessary to correct a district court that "conceived that the right of the accused to a unanimous verdict was a purely statutory right." The court in United States v. Kramer, 955 F.2d 479. 486-87 (7th Cir.), cert. denied, 113 S. Ct. 595 (1992), found the source for the unanimity requirement in Rule 3I(a).

The confusion surrounding the authority for the unanimity rule stems from the Supreme Cour's decisions in the companion cases of Johnson. 406 U.S. at 356, and Apodaca v. Oregon. 406 U.S. 404 (1972), which held that the Sixth Amendment guarantec of a unanimous jury verdict in a cnminal tnal is not applicable to the states through the Fourteenth Amendment. Although the Court did not find a constitutionally mandated unanimity rule at the state level. five Justices in Johnson-the four dissenters and Justice Powell, who concurred in the decision-pointed out that the Sixth Amendment endows a federal criminal defendant with a right to a unanimous jury verdict. Johnson, 406 U.S. at 370. 382 (four dissenting Justices and Justice Powell concluding that unanimity is essential ingredient of Sixth Amendment nght to jury trial); see also Sincox, 571 F.2d at 878 (concluding that Johuson preserved constitutionally guaranteed right to unanimous jury verdict for federal criminal defendants).

Rule 31(a), then, does not supplant the Sixth Amendment as the source of the unanimity requirement: it merely codifies it. United States v. Essex. 734 F.2d 832, 840 (D.C. Cir. 1984) ("This Rule [31(a)] was designed to protect the rights of defendants under the Sixth Amendment to the United States Constitution."); United States v. Morris, 612 F.2d 483, 488-89 (10th Cir. 1979) ("II]n a federal. cnminal case the requirement of unanimity applies not only by reason of [Rule] 31 (a), but also by reason of the Sixth Amendment." (citations omitted)); Gipson, 553 F.2d at 456 ("That rule [31(a)] gives explict recognition to a requirement that the Supreme Court has long assumed to inhere in a federal criminal defendant's sixth amendment right to a trial by jury.").

35. McKoy v. North Carolina, 494 U.S. 433. 449-50 n.5 (1990) (Blackmun. J., concumng): see also United States v. North, 910 F.2d 843, 874 (D.C. Cir. 1990) ("IA] guilty verdict where all jurors agree that he [the defendant] is guilty of something is not sufficient."). But cf. Holland v. State, 280 N.W.2d 288, 292-93 (Wis. 1979) ("Unanimity is required only with respeet to the ultimate issue of the defendani's guilt or innocence of the crime charged ....").

36. As Justice Scalia noted in a rather macabre example:

When a woman's charred body has been found in a bumed house. and there is ample evidence that the defendant set out to kill her, it would be absurd to set him free because six jurors believe he strangled her to death (and caused the fire accidentally in his hasty escape), while 
between these two extremes, courts have interpreted the Sixth Amendment to require unanimous agreement as to the "principal factual elements underlying a specified offense." 37

It is important to note that Sixth Amendment constraints focus on the jury and the judge. The jury must be unanimous as to all principal elements of an offense, and the judge must instruct the jury accordingly. ${ }^{38}$ However, the elements of an offense are defined, in the first instance, by the legislature as it crafts criminal statutes. ${ }^{39}$ While Sixth Amendment requirements frame the issue of verdict specificity, they beg the central question of what, exactly, constitutes a principal factual element. Defining criminal conduct is a task entrusted to the legislature, not the judge or jury; thus, the Sixth Amendment places no constraints on the specificity with which criminal conduct is defined.

\section{B. Due Process Constraints on Defining Criminal Conduct: Schad v. Arizona}

In Schad v. Arizona, the United States Supreme Court explicitly addressed the constitutional constraints legislatures face in defining the elements of a crime. $^{40}$ Edward Harold Schad, Jr. was convicted of first-degree murder and sentenced to death under an Arizona statute that defined the crime as "murder which is . . . wilful, deliberate or premeditated . . or which is committed . . . in the perpetration of, or attempt to perpetrate ... robbery."4l The statute, then, defined the mens rea element of first-degree murder as consisting of

six others believe he left her unconscious and set the fire [intending] to kill her.

Schad v. Arizona, 501 U.S. 624, 650 (1991) (Scalia, J., concurring in part and concurring in the judgment); see also McKoy, 494 U.S. at 449 n.5 (Blackmun, J., concurring) ("This [unanimity] rule does not require that each bit of evidence be unanimously credited or entirely discarded ....").

37. United States v. Ferris, 719 F.2d 1405, 1407 (9th Cir. 1983); see also McKoy, 494 U.S. at 449 n.5 (Blackmun, J., concurring) (quoting Ferris, 719 F.2d at 1407): United States v. Powell, 932 F.2d 1337, 1341 (9th Cir.) (stating jury must unanimously agree on "principal factual elements underlying the offense"), cert. denied, 112 S. Ct. 256 (1991); United States v. Beros, 833 F.2d 455, 461 (3d Cir. 1987) (jury must unanimously agree on "specific act or acts which constitutes . . . [an] offense"); Gipson, 553 F.2d at 457-58 (jurors must "be in substantial agreement as to just what a defendant did as a step preliminary to determining whether the defendant is guilty of the crime charged"). For a general discussion of the factual specificity required by the Sixth Amendment, see Scott W. Howe, Jury Fact-Finding in Criminal Cases: Constitutional Limits on Factual Disagreements Among Convicting Jurors, 58 MO. L. RBV. 1,19 \& n.87 (1993).

38. See infra notes $129-32$ and accompanying text.

39. Sometimes essential elements are read into criminal statutes by courts interpreting the statutes according to legislative intent. In either case, the legislature determines the level of verdict specificity required by the Sixth Amendment.

40. 501 U.S. 624 (1991).

41. ARIZ. REV. STAT. ANN. \$ $13-452$ (Supp. 1973). The full statute provided:

A murder which is perpetrated by means of poison or lying in wait, torture or by any other kind of wilful, deliberate or premeditated killing, or which is committed in avoiding or preventing lawful arrest or effecting an escape from legal custody, or in the perpetration of, or attempt to perpetrate, arson, rape in the first degree, robbery, burglary, kidnapping, or mayhem, or sexual molestation of a child under the age of thirteen years, is murder of the first degree. All other kinds of murder are of the second degree.

The statute has since been revised, but both premeditated and felony murder still constitute first-degree murder. See id. \& 13-1105.A (Supp. 1989). 
either premeditation or intent to commit robbery. At Schad's trial, the state advanced theories of both premeditated and felony murder. The trial court treated the two theories as alternative means of fulfilling the mens rea requirement of the statute and did not instruct the jury that it had to agree unanimously on one theory. As a result, the trial court's instruction allowed for the possibility of a patchwork guilty verdict. Schad may have been convicted of first-degree murder by six jurors who thought he committed premeditated murder and six jurors who thought he committed felony murder. Schad challenged his conviction on the ground that the trial court deprived him of his right to a unanimous verdict in a state capital case guaranteed by the Sixth, Eighth, and Fourteenth Amendments. ${ }^{42}$

The U.S. Supreme Court upheld Schad's conviction. Recognizing that the heart of the dispute lay not in the jury instruction, but in the statutory definition of first-degree murder, the plurality ${ }^{43}$ recharacterized the claim as "one of the permissible limits in defining criminal conduct, as reflected in the instructions to jurors applying the definitions [of elements of a crime], not one of juror unanimity." legislature's power to define criminal conduct, all of the Schad opinions analyzed it not under the Sixth Amendment, but under the Due Process Clause of the Fourteenth Amendment. ${ }^{45}$

Due process analysis under Schad begins with the proposition that "it has long been the general rule that when a single crime can be committed in

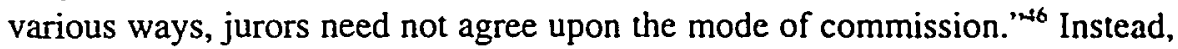
jurors need only agree unanimously upon those facts that are "material" or "necessary to constitute the crime." that are "mere alternative means" of fulfilling the necessary elements of the crime. ${ }^{48}$ In addition, distinctions between facts as principal elements of a

42. Schad, 501 U.S. at 629-30 (Souter, J., plurality opinion),

43. Justice Souter wrote the plurality opinion in Schad. joined by Chief Jusuce Rehnquist and Jusuces O'Connor and Kennedy. Justice Scalia wrote a separate opinion, concumng in the judgment and concumng with the plurality opinion only as to a part not relevant to this Note. Finally. Justice White wrote a dissenting opinion, joined by Justices Marshall, Blackmun, and Stevens.

44. Schad, 501 U.S. at 631 (Souter, J., plurality opınion). Similarly. Justuce Scalıa defined the question at issue as whether the Arizona first-degree murder statute's definition of the crime was contrary to due process. See id. at 650 (Scalia, J., concurring in par and concurring in the judgment). Jusuce White characterized the question in a slightly different way. but. nonetheless. engaged in a due process. not a Sixth Amendment, analysis. He wrote for the dissenters. "While a State is free to construct a statute in this way, it violates due process for a State to invoke more than one statutory altematuve, each with different specified elements, without requiring that the jury indicate on which of the alternatives 11 has based the defendant's guilt." Id. at 656 (White, J., dissenting) (emphasis added).

45. Id. at 634 n.5 (Souter, J., plurality opinion), 6-49-50 (Scalia, J., concurnng in part and concumng in the judgment), 656 (White, J., dissenting).

46. Id. at 649 (Scalia, J., concurring in part and concumng in the judgment). While these words are taken from Scalia's opinion, the plurality also begins with this proposituon, noung. "We have never suggested that in rewring general verdicts ... the jurors should be required to agree upon a single means of commission ...." Id. at 631 (Souter, J., plurality opinıon).

47. Id. at 638 .

48. See id. at 631-32. 
crime, which require unanimity, and facts as mere means of fulfilling the elements of a crime "represent value choices more appropriately made in the first instance by a legislature than by a court." ${ }^{\prime 49}$

The legislature, however, may not define criminal conduct in any way it pleases. Instead, due process limits "a [legislature's] capacity to define different courses of conduct, or states of mind, as merely alternative means of committing a single offense, thereby permitting a defendant's conviction without jury agreement as to which course or state actually occurred." 50 For instance, the Due Process Clause would not sanction a crime defined "so generic[ally] that any combination of jury findings of embezzlement, reckless driving, murder, burglary, tax evasion, or littering" would support a conviction. ${ }^{51}$ Thus, when the legislature formally defines different courses of conduct not as independent elements of a crime, but as alternative means of satisfying an actus reus or mens rea element of a crime, due process scrutiny is necessary. ${ }^{52}$

Convinced of the impracticality of trying to construct a single due process test for the level of definitional and verdict specificity required by the Constitution, the Schad plurality set forth a loosely defined fundamental fairness test that looked to "history and wide practice... as well as to narrower analytical methods of testing the moral and practical equivalence" of alternative means of satisfying a principal factual element of an offense. ${ }^{53}$ In examining the history and wide practice of using certain alternative means of satisfying an element of an offense, the plurality looked to the historical and contemporary acceptance of the definition of the element in question. When a definition of a crime "has a long history, or is in widespread use," it is unlikely that the defendant will be able to show that the definition violates due process. ${ }^{54}$ In examining the moral and practical equivalence of the different means of satisfying an element, the plurality attempted to assign levels of "blameworthiness" to the different means. Only if the alternative means "reasonably reflect notions of equivalent blameworthiness or culpability" does the statutory definition pass constitutional muster..$^{55}$ Arizona's first-degree murder statute passed both inquiries of the plurality's due process test.

Concurring in the judgment, Justice Scalia agreed that the Arizona statute was consistent with due process but disagreed as to exactly what defines the

49. Id.

50. Id. at 632 .

51. Id. at 633 .

52. While the Schad opinions addressed a combination of findings best described as alternative mental states, the plurality implied that the due process limits on defining crime applied equally to actus reus requirements. Id. at 632 ("We see no reason, however, why the rule that the jury need not agree as to mere means of satisfying the actus reus element of an offense should not apply equally to alternative means of satisfying the element of mens rea.").

53. Id. at 637.

54. Id. at 640 .

55. Id. at 643 . 
process "due" under the Constitution. According to Scalia, due process is defined solely by "historical practice." " "Th[e] requirement of [due process] is met if the trial is had according to the settled course of judicial proceedings. Due process of law is process due according to the law of the land." 37 Because Arizona's first-degree murder statute had "the endorsement of history,"

Writing for the dissent, Justice White agreed that the Arizona statute must be judged against the Due Process Clause of the Fourteenth Amendment, but concluded that the statute ran afoul of the fundamental fairness due process requires. ${ }^{60}$ Unlike the plurality and Justice Scalia, the dissent did not set forth an explicit due process test by which to measure a statute that allows a single crime to be established through evidence of alternative courses of conduct. The logic of the dissent, however, reveals a sensical, if ultimately inconclusive, test for determining the facts upon which a jury must unanimously agree in order to provide due process.

The Schad dissenters began by noting that due process prescribes and assigns the burdens of proof in criminal cases. In the case of In re Winship, ${ }^{61}$ Justice White noted, the Court held that "due process mandates "proof beyond a reasonable doubt of every fact necessary to constitute the crime with which [the defendant] is charged." 62 Therefore, no legislature may define a crime so that a lesser standard of proof applies to any of the facts necessary to constitute the crime.

The logic of the dissent suggests that the same due process standard that identifies the facts that the prosecution must prove beyond a reasonable doubt should also identify those facts upon which the jury must unanimously agree. $^{63}$ The jury, then, must unanimously agree upon every fact "necessary

56. Id at 651 (Scalia, J., concurring in part and concurring in the judgment) ("[l]t is tmpossible that a practice as old as the common law and still in existence in the vast majority of States does not provide that process which is 'due'.").

57. Id. at 652 (quoting Walker v. Sauvinet, 92 U.S. 90,93 (1876)) (alterations in onginal).

58. Id. at 651 .

59. See id Scalia explained, "[Arizona's definition of first-degree murder] was the norm when thus country was founded, was the norm when the Fourteenth Amendment was adopled in 1868, and remains the norm today." Id.

60. See id at 652-59 (White, J., dissenting).

61. 397 U.S. 358 (1970).

62. Schad, 501 U.S. at 652 (White, J., dissenting) (quoting Winship. 397 U.S. at 36-4) (alteration in original).

63. This position does not imply that the beyond-a-reasonable-doubt standard and the unanimity rule are somehow indispensable to one another. In fact, it is easy to conceive of a jury system in which we require individual jurors to be convinced beyond a reasonable doubt in order to vote to convict. but do not require that the jury as a whole be unanimous in its verdict of guilty. See Johnson v. Louisiana, 406 U.S. 356, 359-65 (1972) (holding that Constitution does not require unanimous jury verdicts in state criminal trials but not questioning beyond-a-reasonable-doubt standard set forth in Winship). A jury is not "a single, holistic entity," in which the dissent of three jurors would prevent "the jury" from finding facts beyond a reasonable doubt. Trubith, supra note 26 , at 476 . Rather, a jury is made up of 12 individuals, and any one juror may be convinced beyond a reasonable doubt regandless of the beliefs the other jurors hold. See id. 
to constitute the crime" with which the defendant is charged. Unlike the plurality or Justice Scalia, the Schad dissent does not give courts an extrinsic measurement such as "history" or "blameworthiness" by which to compare alternate means of committing a crime. It does imply, however, that if jurors must be convinced of a fact beyond a reasonable doubt under In re Winship, the Due Process Clause requires the jury to be unanimous as to that fact as well.

While the vaguely defined due process inquiries articulated by the different opinions in Schad leave much to be desired, ${ }^{64}$ they provide a more effective means of separating significant from insignificant verdict specificity problems than did previous tests put forth by the lower courts. Using the Sixth Amendment as their guide, lower courts have articulated numerous tests for distinguishing facts requiring unanimity from those that do not. These tests fall into three broad categories. First, many courts have held that a legitimate nonconcurrence claim exists only if the evidence under a single charge or statute contains two or more separate crimes. ${ }^{65}$ Second, other courts have adopted a "distinct acts" test, stating, for example, "When distinct proof is

Nowhere is this commitment to individualism more evident than in Johnson and the companion casc of Apodaca v. Oregon, 406 U.S. 404 (1972). In Apodaca, Justice White, writing for a plurality of the Court, stated, "The reasonable-doubt standard developed separately from both the jury trial and the unanimous verdict." Id. at 411. In Johnson, writing for a majority of the Court, White noted that "want of jury unanimity is not to be equated with the existence of a reasonable doubt." Johnson, 406 U.S. at 363.

Despite these clear indicia that both Justice White and the Court understand the unanimity rule and the beyond-a-reasonable-doubt standard to be separate concepts, one commentator has interpreted White's Schad dissent as meaning "that the possibility of juror divergence on the mens rea elements of first degreo munder under the Arizona statute created a reasonable doubt which would make the conviction unconstitutional under due process standards." Katherine L. Harvey, Note, United States v. Canino and the Continuing Criminal Enterprise: Do Drug Kingpins Have a Right to Specific Juror Agreement?, 15 W. NEW ENG. L. REV. 271, 301 (1993). This reading flies in the face of White's reasoning in Johnson and Apodaca and reflects a mistake commonly made by courts and commentators. See United States v. Esscx, 734 F.2d 832, 841 (D.C. Cir. 1984) ("The requirement of unanimity for a verdict in a criminal case is inextricably interwoven with the standard of proof beyond a reasonable doubt." (internal quotation marks omitted)); Hibdon v. United States, 204 F.2d 834, 838 (6th Cir. 1953) ("[T]here cannot be a verdict supported by proof beyond a reasonable doubt if one or more jurors remain reasonably in doubt as to guilt."); Harvey, supra, at 292 ("The constitutional mandate of the 'proof beyond a reasonable doubt' standard in criminal cases reveals the Court's recognition of the necessity of factual concurrence among convicting jurors." (footnote omitted)).

This is not to say, however, that the two standards are entirely unrelated. In fact, the reasonable doubt standard gives content to the unanimity requirement. It would be much easier for a criminal jury to reach a unanimous guilty verdict if jurors did not need to be convinced beyond a reasonable doubt of the defendant's guilt. See Elizabeth R. Carty, Note, Schad v. Arizona: Jury Unanimity on Trial, 42 CATH. U. L. REV. $355,366 \mathrm{n} .82$ (1993). Similarly, the unanimity rule requires a jury to engage in robust deliberation that may affect the beliefs of individual jurors, convincing them that a fact was, or was not, pruven beyond a reasonable doubt.

64. For criticisms of the Schad plurality test, see Howe, supra note 37, at 5 (arguing that Schad offers "little illumination" of factual divergence problems); James J. McGuire, Note, Schad v. Arizona: Diminishing the Need for Verdict Specificity, 70 N.C. L. REv. 936, 958 (1992) (criticizing "moral equivalence" prong of test as "absurd"). Most of the criticisms of Schad center around the difficulty of applying the "moral equivalence" prong of the plurality test.

65. See Howe, supra note 37, at 26 (collecting cases). 
required to establish distinct affirmative acts as elements of an offense, specific unanimity is necessary."

Finally, the most widely used pre-Schad test for distinguishing between significant and insignificant nonconcurrence problems was articulated in United States v. Gipson. ${ }^{67}$ In Gipson, the Fifth Circuit held that specific unanimity is required as to alternative courses of conduct only when they do not fall into a single "distinct conceptual grouping." explicitly declined to utilize the Gipson test, deeming it "too indeterminate to provide concrete guidance to courts faced with verdict specificity questions." 69

Indeed, all of the pre-Schad tests suffer from this fatal indeterminacy. Because they are based on the Sixth Amendment, the tests include no a priori standard to determine the appropriate level of specificity. As a result, each of these tests begs the question central to verdict specificity problems. It is precisely the permissible limits of "crimes," "acts," or "distinct conceptual groupings" that are at issue. While the Schad due process tests may be difficult to apply with consistency and accuracy, the plurality and Scalia tests offer at least the a priori yardsticks of history and blameworthiness by which to measure definitions of crimes and their elements.

\section{A Constitutional Framework}

As the foregoing analysis demonstrates, the Sixth Amendment alone cannot offer a solution to problems of patchwork verdicts. When the straightforward Sixth Amendment unanimity analysis is supplemented with Fifth Amendment due process analysis, however, the Constitution offers a framework through which we can answer difficult questions of juror unanimity and verdict specificity in federal compound-complex crimes. The Sixth Amendment focuses on the judge and the jury and mandates that the jury be unanimous as to all principal factual elements of a crime. But Sixth Amendment constraints beg the question of exactly what may constitute a "principal factual element" requiring unanimity and what may be defined as "mere alternative means" of

66. United States v. Duncan, 850 F.2d 1104, 1113 (6th Cir. 1988); see also Howe, supra note 37, at 36-39 (collecting cases). Other courts have broadened the distinct acts test into a transaction-based "disunct incidents" test. See, e.g., Scarborough v. United States, 522 A.2d 869. 873 (D.C. 1987) ("This unanimity requirement is applicable whenever there is evidence tending to show legally separate incidents ... . ): Derrington v. United States, 488 A.2d 1314. 1336 (D.C. 1985) ("separately chargeable incıdents"); Hawkins v. United States, 434 A.2d 446, 449 (D.C. 1981) ("separate incidents"); State v. Franco, 639 P.2d 1320. 1322 (Wash. 1982) ("same transaction").

67. 553 F.2d 453 (5th Cir. 1977).

68. Id. at 458; see also United States v. North, 910 F.2d 843, 876-77 (D.C. Cir. 1990) (applynng Gipson's "distinct conceptual groupings" test); Duncan, 850 F.2d at 1110-11 (applyıng "distinct conceptual groupings" test in addition to "distinct acts" test): United States v. Peterson, 768 F.2d 64, 66-67 (2d Cir.) (applying Gipson's "distinct conceptual groupings" test), cert. denied, 474 U.S. 923 (1985).

69. Schad v. Arizona, 501 U.S. 624, 635 (1991). 
fulfilling that element. Due process constraints, on the other hand, address this question by limiting the legislature's freedom to define alternate courses of conduct as mere means rather than elements.

This conceptual framework applies neatly to compound-complex crimes. Whenever a federal district court must ask a jury to apply a compoundcomplex criminal statute and the prosecution presents evidence of more than the requisite number of predicate acts, the court must determine whether the legislature intended the predicates to be principal factual elements of the offense or mere means of fulfilling the "pattern" or "series" element. If the predicates are held to be principal factual elements, unanimity is, of course, required as to each predicate act underlying a guilty verdict, ${ }^{70}$ and the statute need not be subjected to due process scrutiny. If the court does not interpret the predicate acts to be principal factual elements of the crime, it must determine whether Congress has overstepped the limits imposed by the Due Process Clause on its power to define criminal conduct. ${ }^{71}$ If the statute survives due process scrutiny, the jury need not unanimously agree upon which predicate acts form the basis of a conviction. If, however, the statute fails the due process test, the court must declare the statute unconstitutional as applied to cases in which the prosecution offers evidence of more than the requisite number of predicate acts.

\section{ANAlyzing Patchwork Verdicts IN COMPOUND-COMPLEX CRIMES}

The circuit courts' jurisprudence surrounding unanimity as to predicate acts is confused. Debate over the status of the predicate acts constituting a "continuing series" for the purposes of the CCE statute, in particular, has generated a split in the circuits: The Third Circuit has determined that CCE predicates are principal elements of the offense, requiring unanimity, while the Seventh Circuit and the D.C. Circuit have held these predicates to be mere means of fulfilling the continuing series element of the crime. Although many courts have considered the question of unanimity as to predicate acts in compound-complex crimes, only a single case has subjected such a statute to the due process scrutiny demanded by Schad v. Arizona. Unfortunately, that case, United States v. Anderson, ${ }^{72}$ did not carefully apply the Schad due

70. If there is a genuine risk that the jury will be confused or that a conviction may occur as the result of different jurors concluding that a defendant committed different acts, the judge must enforce the Sixth Amendment unanimity requirement with a specific unanimity instruction. See infra notes 129-32 and accompanying text.

71. While Schad analyzed Arizona's first-degree murder statute under the Due Process Clause of the Fourteenth Amendment, this Note deals only with federal compound-complex crimes. Congress' actions are constrained by the Due Process Clause of the Fifth Amendment.

72. 39 F.3d 331 (D.C. Cir. 1994). 
process inquiries and, as a result, articulated an incomplete analysis and reached an incorrect conclusion. ${ }^{73}$

The due process tests of the Schad plurality, concurrence, and dissent all demonstrate that, given the number and breadth of eligible predicate acts in federal compound-complex criminal statutes, predicate acts must be considered elements of the offense if these statutes are to pass constitutional muster. Therefore, the Fifth and Sixth Amendments demand that a jury in a federal criminal trial unanimously agree upon the identity of the predicate acts constituting the continuing series or pattern before it may convict a defendant of participating in a compound-complex crime.

\section{A. A Split in the Circuits as to CCE Predicate Acts}

The first step in determining whether unanimity is required as to predicate acts is to ascertain whether the legislature, in defining the compound-complex crime at issue, intended the predicate acts to be principal elements of the offense or mere alternative means of fulfilling the series or pattern element of the crime.$^{74}$ This question has arisen most explicitly and contentiously in the context of the CCE. As the cases attempting to define the CCE demonstrate, the status of predicate acts is by no means self-evident; indeed, the circuits have split as to how to categorize and treat predicates.

The only two circuits to analyze comprehensively the status of CCE predicates under the Sixth Amendment have arrived at directly contradictory conclusions, which serve as paradigms for the alternative treatments of compound-complex predicates. In United States v. Echeverri, ${ }^{75}$ the Third Circuit determined that the predicate acts constituting a continuing series were essential elements of the CCE offense; therefore, the Sixth Amendment required that a jury unanimously agree as to the identity of the three predicate acts underlying a conviction. In United States $v$. Canino, ${ }^{76}$ on the other hand, the Seventh Circuit held that CCE predicate acts were not principal factual elements of the offense; but rather were mere alternative means of fulfilling the continuing series element of the crime. Therefore, the Canino court found no constitutional requirement that a convicting jury unanimously agree as to the identity of the predicate acts constituting the continuing series.

So far, only one court has analyzed CCE predicates under the Fifth Amendment. In United States $v$. Anderson, ${ }^{n}$ the United States Court of Appeals for the District of Columbia determined, in a cursory and flawed analysis, that due process does not demand CCE predicates to be treated as

\footnotetext{
73. See infra notes $77,101-04$ and accompanying text.

74. See supra text accompanying notes $70-71$.

75. 854 F.2d 638 (3d Cir. 1988).

76. 949 F.2d 928 (7th Cir. 1991), cert. denied, 112 S. C. 1940 (1992).

77. 39 F.3d 331 (D.C. Cir. 1994).
} 
principal factual elements. This split in the circuits and the lack of a complete and coherent due process analysis by the courts make compound-complex predicates ripe for thoughtful treatment under Schad.

\section{United States v. Echeverri: Predicates as Elements}

In Echeverri, the Third Circuit considered the CCE conviction of Elkin Echeverri. At Echeverri's trial, the government offered testimony concerning a "plethora of drug-related activity."78 At the close of evidence, Echeverri requested a jury instruction reading, "You must unanimously agree on which three acts constitute the continuing series of violations."79 The district court, however, refused to adopt this or a similar charge and issued only the general unanimity instruction given at all federal criminal trials. Echeverri was convicted of participating in a continuing criminal enterprise and appealed his conviction on the ground that the general unanimity instruction deprived him of his Sixth Amendment right to a unanimous verdict in a federal criminal trial. $^{80}$

The Third Circuit reversed Echeverri's CCE conviction, holding that the predicate acts constituting the continuing series were elements of the offense and required unanimity. The Echeverri court recognized that the CCE statute, on its face, does not specify that a continuing series must be composed of three violations of federal narcotics laws; ${ }^{81}$ rather, this requirement resulted from judicial interpretation of the CCE statute. ${ }^{82}$ However, the court recognized no valid distinction between requirements appearing in the language of the statute and those judicially recognized through statutory interpretation because in each case "congressional intent is the touchstone." 83 The CCE statute requires the jury to find that the defendant participated in a continuing series consisting of three violations of federal drug laws. Therefore, the Echeverri court held, each predicate act is an "essential element[] of the crime charged." 84 As such, each predicate underlying a conviction must be unanimously agreed upon by the jury. ${ }^{85}$

78. Echeverri, 854 F.2d at 642 .

79. Id.

80. Id.

81. Id. at 643.

82. Id. For cases interpreting "continuing series" as requiring three violations of federal narcotics statutes, see sources cited supra note 20.

83. Echeverri, 854 F.2d at 643.

84. Id.

85. Id. It is important to note that because the Echeverri court found the predicate acts to be elements of the offense that required unanimity, no due process analysis was necessary. 


\section{United States v. Canino: Predicates as Alternative Means}

In United States $v$. Canino, ${ }^{86}$ the Seventh Circuit applied Sixth Amendment constraints to a similar situation and reached a very different result. Michael John Canino was convicted of engaging in a continuing criminal enterprise. At trial, the government introduced evidence of Canino's involvement in five federal drug offenses. ${ }^{87}$ The trial judge did not instruct the jury that it had to agree unanimously on which drug offenses constituted the continuing series necessary for a conviction. ${ }^{88}$ Like Echeverri, Canino challenged his conviction as violative of his Sixth Amendment right to a unanimous verdict.

Unlike the Third Circuit, the Seventh Circuit determined that CCE predicate acts are not principal factual elements of the CCE offense. In interpreting the statute, the Canino court, too, took legislative intent as its guide. Congress, in passing the CCE statute, intended to thwar "large-scale," "continuing," and "enduring" drug operations. ${ }^{89}$ The identity of the specific drug violations that demonstrate the existence of the enterprise is "irrelevant" to proving the size and duration of an enterprise. ${ }^{90}$ Instead, the prosecution may prove the requisite size and duration through "proof of the defendant's commission of a threshold number of criminal drug violations." specific predicate act is an element of the CCE offense, "conviction is warranted once each juror finds beyond a reasonable doubt that a CCE defendant committed at least [the requisite number of] predicate offenses." 92 The court upheld Canino's conviction and endorsed the practice of giving only

86. 949 F.2d 928 (7th Cir. 1991), cert. denied, 112 S. Ct. 1940 (1992).

87. With five eligible predicate offenses, the jurors had 10 unique combinations of predicate acts on which to base a conviction. See supra note 30 .

88. Canino, 949 F.2d at $945-46$.

89. Id at 947.

90. Id. at 948 .

91. Id. at 947 (emphasis added). The court went on to state:

Juror unanimity seems functionally incongruous with the purposes of the CCE . . . If the jurors (being instructed that three predicate acts are necessary) were required to agree on which three predicate acts constituted the "continuing series" the defendant would be acquitted, despite the fact that everyone believed beyond a reasonable doubt that he was involved in three crimunal acts. This result is at odds with the purpose of the CCE which is interested in punishing a defendant whom the jury is convinced was involved in a related series of drug activity with relevant frequency. It is the defendant's demonstrated frequency in participating in conspiratorial drug offenses that is the focus of the CCE offense, rather than any particularization of the acts used to demonstrate "continuous."

Id. at 948 n.7; see also Harvey, supra note 63 (describing generally the Canino courr's approach to juror unanimity problems).

92. Canino, 949 F.2d at 947 (emphasis added). The cour later rephrased this requirement: "A conviction under the CCE is justified when the jury has a unanimously agreed sense that the defendant exhibited such conspirational frequency rather than a shared sense of what those acts may have been." ld. at 948 n.7 (emphasis added) (emphasis omitted). The court did not explain exactly what it meant by a "unanimously agreed sense." 
general unanimity instructions in CCE cases in which the prosecution presents evidence of more than the requisite number of predicate acts.

Upon finding that $\mathrm{CCE}$ predicates are mere alternative means of fulfilling the continuing series element of the CCE offense, the Canino court did not perform the next step required by the analytical framework proposed in this Note; it did not subject the statute, as applied in Canino's case, to due process scrutiny. ${ }^{93}$ In fact, in response to Canino's concerns that the eligible predicates were too disparate in kind to be proscribed by the same statute-a challenge sounding in the due process language of Schad-the Canino court flouted due process constraints: "The expansive breadth of culpable offenses suitable for CCE treatment diminishes our need to ascertain precisely what acts each juror finds attributable to the defendant, and instead permits us to focus on whether the jury is convinced that the defendant performed these conspiratorial acts with the required frequency." It is precisely this "expansive breadth" of alternative means that due process constraints are meant to combat. It makes absolutely no sense in due process terms to cite the vast number and variety of eligible predicate acts as militating against requiring unanimity as to those predicates. Rather, courts should apply the Schad test with greater diligence to statutes most resembling the "umbrella" crimes decried by all of the Justices in Schad. The more ways to violate a statute, the more likely the statute violates due process.

\section{Due Process Constraints Are Widely Ignored}

The Canino court is not alone in ignoring the due process implications of treating predicate acts as mere means of fulfilling an element of a compoundcomplex offense. For instance, the court in United States v. Young indicated that the government need not prove any particular CCE predicate acts at trial, but "may instead simply prove . . the continuing series of offenses." 95 The court did not follow this pronouncement with a due process analysis of the CCE statute. ${ }^{96}$

In fact, the only court to apply the due process test of Schad to any part of a compound-complex statute is the Court of Appeals for the District of Columbia. First, in United States v. Harris, ${ }^{97}$ the court applied both the plurality and Scalia due process tests of Schad and held that jurors need not

93. The Seventh Circuit heard oral arguments in Canino on April 4, 1991, two months before the Supreme Court decided Schad on June 21, 1991. However, the Canino decision was handed down on November 27, 1991, a full five months after Schad was decided.

94. Canino, 949 F.2d at 946 n.6 (emphasis added). (1985).

95. 745 F.2d 733, 747 (2d Cir. 1984), cert. denied sub nom. Myres v. United States, 470 U.S. 1084

96. See also United States v. Kramer, 955 F.2d 479 (7th Cir.) (following Canino precedent), cert. denied, 113 S. Ct. 595 (1992).

97. 959 F.2d 246 (D.C. Cir.), cert. denied sub nom. Palmer v. United States, 113 S. Ct. 364 (1992). 
be unanimous as to the identity of the five people whom a CCE defendant supervised. The five-person requirement, the court noted, has a historical analogue in the law of conspiracy, which generally has not required jurors to identify the defendant's co-conspirators. ${ }^{98}$ In addition, it is "beyond dispute" that acting in concert with one group of five persons is the moral equivalent of acting in concert with another group of five." "Thus, under Schad, the Due Process Clause permits different people to serve as 'alternative means' of satisfying the CCE five-person requirement."100

In United States $v$. Anderson, ${ }^{101}$ the D.C. Circuit extended its holding in Harris, stating that due process does not require jurors to agree unanimously as to the specific predicate acts constituting the continuing series under the CCE statute. Instead of providing a thoughtful, reasoned extension of Harris, the Anderson case merely broadens the Harris decision without independently evaluating CCE predicate acts under Schad. After briefly discussing Harris, the Anderson court simply stated, "We see no reason to treat a finding of predicate acts differently [than the five-person requirement]."102

In fact, closer examination reveals that the CCE predicate-act requirement differs significantly from the CCE five-person requirement and presents several reasons to treat the two requirements differently under the Schad due process tests. First, unlike the five-person requirement, which has a historical analogue in the law of conspiracy, the CCE predicate-act requirement has no historical equivalent. ${ }^{103}$ In addition, in marked contrast to the five-person requirement, it is by no means "beyond dispute" that committing one set of three predicate acts is the moral equivalent of committing another set of three predicate acts. Indeed, given the number and breadth of eligible predicate acts in federal compound-complex criminal statutes, one set of eligible predicate acts may be significantly more or less blameworthy than another. ${ }^{104}$

Anderson presents only a superficial and ultimately flawed due process analysis of predicate acts. In light of the frequency with which prosecutors present evidence of more than the requisite number of predicate acts in CCE

98. Harris, 959 F.2d at 256.

99. Id. at $256-57$.

100. Id at 257. All but one of the courts of appeals considering the five-person requirement of the CCE statute have held that the Constitution does not require the jury to agree on the identities of the individuals whom the defendant managed or supervised. Harvey, supra note 63, at 281: see. e.g.. United States v. Linn, 889 F.2d 1369, 1374 (5th Cir. 1989) ("So long as the jurors unanimously agree that the defendant supervised, organized, or managed any five persons, this element of a CCE volation is satisfied."), cert. denied, 498 U.S. 809 (1990). The exception to this trend is the Ninth Circuit, which holds that the evidence of persons involved creates a genuine risk of juror confusion and, therefore, requires a specific unanimity instruction. See United States v. Beltran-Penuelas, No. 93-10286, 1994 U.S. App. LEXIS 22035 (9th Cir. Aug. 12, 1994); United States v. McCullough. No. 90-10577. 1994 U.S. App. LEXIS 18011 (9th Cir. July 14, 1994); United States v. Jerome, 942 F.2d 1328 (9th Cir. 1991). No case other than Harris, however, has subjected the five-person requirement to due process analysis.

101. 39 F.3d 331 (D.C. Cir. 1994).

102. Id at 350 .

103. See infra notes $108-11$ and accompanying text.

104. See infra text accompanying notes 121-22. 
trials, ${ }^{105}$ due process scrutiny of the "continuing series" requirement and its predicates is long overdue.

\section{B. Due Process Demands that Predicates Be Considered Principal Factual Elements of Compound-Complex Crimes}

Under the Due Process Clause of the Fifth Amendment, convictions under compound-complex criminal statutes are unconstitutional when the prosecution presents evidence of more than the requisite number of predicate acts unless the judge interprets the predicate acts as principal elements of the offense and requires specific unanimity. This conclusion is inevitable under both the plurality and Scalia tests in Schad because the use of predicate acts has no historical analogue and because alternate series or patterns of predicate acts likely reflect differing notions of blameworthiness. In addition, no court considering predicate acts has suggested that each juror need not be convinced beyond a reasonable doubt of the specific predicates underlying his or her vote of guilty; therefore, predicate acts require unanimity according to the logic of Justice White's Schad dissent as well. In most instances in which compoundcomplex statutes are applied, the Fifth and Sixth Amendments demand that a convicting jury unanimously agree upon the specific predicate acts constituting the series or pattern requirement.

\section{Historical Practice}

In Schad, both the plurality and Justice Scalia agreed that due process fundamental fairness is defined, at least in part, by historical practice. ${ }^{106}$ Unlike the five-person requirement of the $\mathrm{CCE}$, which has a historical analogue in conspiracy law, ${ }^{107}$ the predicate-act requirement is a relatively new phenomenon in criminal law. ${ }^{108}$ None of the compound-complex crimes is at all similar to the Arizona first-degree murder statute upheld in Schad, which was "the norm when this country was founded." complex statutes are more akin to the "novel 'umbrella' crimes" such as "a felony consisting of either robbery or failure to file a tax return," which "would seem contrary to due process." 110 In fact, if compound-complex crimes do have a historical analogue, it is in the broadly defined common law

105. See supra notes $28-30$ and accompanying text.

106. See supra text accompanying notes 53-59.

107. See supra text accompanying note 98.

108. See supra text accompanying notes 12-15.

109. Schad v. Arizona, 501 U.S. 624, 651 (1991) (Scalia, J., concurring in part and concurring in the judgment).

110. Id. at 650 
crimes that courts have long since declared unconstitutionally vague."I Hence, compound-complex statutes fail Scalia's due process test.

The plurality opinion in Schad does carve out an exception to the use of history as a guide to fundamental faimess, noting, " $[\mathrm{H}]$ istory will be less useful as a yardstick in cases dealing with modern statutory offenses lacking clear common law roots than it is in cases ... that deal with crimes that existed at common law."112 While compound-complex crimes are "modern statutory offenses," 113 they deal with crimes that have clear common law roots: smuggling, extortion, fraud, theft, murder, etc. Their reliance on predicate acts does not create new crimes as much as construct a novel way of defining old ones. It is precisely this type of novel definition of traditionally recognized crimes that the Schad due process tests are meant to check. ${ }^{1 / 4}$

\section{Equivalent Blameworthiness}

In addition to utilizing history and common practice in determining what fundamental fairness requires, the Schad plurality found that, in order to pass constitutional muster, alternative means of satisfying an element of an offense must reflect notions of equivalent blameworthiness or culpability." Compound-complex statutes define hundreds of different combinations of predicate offenses that could potentially satisfy the "series" or "pattern" requirements of the statutes. ${ }^{116}$ For instance, the continuing series element of the CCE offense could be met by proof of three instances of simple possession of a controlled substance; ${ }^{17}$ it could also be met by proof of three instances of importing or exporting a shipload of controlled substances. ${ }^{118}$ While any single jury's choices may not be this extreme, the prosecution often presents

111. For instance, the court in State v. Palendrano, 293 A.2d 747 (N.J. Super. Ct. Law Div 1972). declared unconstitutionally vague the common law crime of being a "common scold." Being a common scold could consist of brawling, wrangling, breaking the public peace, increasing discord, and/or being a nuisance. Id. at 748 . In fact, similar to committing compound-complex crimes, being a common scold "does not consist of a single act, but in an habitual course of conduet: therefore. the element of contunuity is essential, and there must be a habit or practice of scolding." Id. The Palendrano courn's emphasis on continuity and frequency bears a striking resemblance to the Canino court's emphasts on the "conunung" and "enduring" nature of drug crimes targeted by the CCE. See supra text accompanying note 89. Of course, the Palendrano court declared the crime of being a common scold unconstitutionally vague, while the Canino court found the $\mathrm{CCE}$ predicates consistent with the constitutional unanimity requirement.

112. Schad, 501 U.S. at 640 n.7 (Souter, J., plurality opinion).

113. Id.

114. Compound-complex crimes are not unlike the hypothetical crimes condemned by the Schad plurality as "so generic that any combination of jury findings of embezzlement. reckless driving, murder. burglary, tax evasion, or littering, for example, would suffice for conviction." Id. al 633.

115. See supra text accompanying note 55.

116. See supra notes $22-23,30$ and accompanying text.

117. See 21 U.S.C. $\$ 844$ (1988 \& Supp. IV 1992); see also supra notes 19-22 and accompanying text. Similarly, a RICO series may be made up of two instances of dealing in obscene matenal or two instances of murder. 18 U.S.C. $\$ 1961$ (1)(A), (5) (1988).

118. See 21 U.S.C. § 960(a)(2) (1988); see also supra notes 19-22 and accompanying text. 
evidence of many and varying predicate acts. ${ }^{119}$ When the prosecution presents evidence of more than the requisite number of predicate acts, many potentially incriminating combinations are possible. ${ }^{120}$ In most cases where several incriminating combinations of predicate acts are possible, it is highly unlikely that all alternative combinations are equally blameworthy or equally culpable.

In fact, the sentencing provisions of the federal drug laws that define the individual predicates reinforce the proposition that not all CCE predicates (and, therefore, all combinations of predicates) are equally blameworthy. For instance, each count of simple possession carries a maximum penalty of one year imprisonment, a fine of not less than $\$ 1000$, or both. ${ }^{121}$ Each count of importation of a controlled substance, on the other hand, carries a maximum penalty of life imprisonment, a fine of not more than $\$ 4$ million, or both. ${ }^{122}$ If the penalties are intended to reflect some notion of culpability or blameworthiness, these two offenses cannot be equal in the eyes of due process. Yet, the CCE statute treats them as if they are.

\section{Reasonable Doubt}

The Schad dissent also supports the notion that juries must be unanimous as to the predicate acts supporting a compound-complex conviction. While the Schad dissent does not set out a well-defined due process test, the logic of the opinion suggests that the test for what constitutes a necessary fact that must be proven beyond a reasonable doubt should also identify those facts upon which a jury must unanimously agree. ${ }^{123}$ No court considering whether a jury must unanimously agree on the predicate acts underlying a compound-complex conviction has suggested that a standard of proof less than "beyond a reasonable doubt" be applied to predicates. The Canino court, for instance, held that "once each juror finds beyond a reasonable doubt that a CCE defendant committed at least [the requisite number] of predicate offenses ... the defendant is suited for punishment consistent with the statute."124 If predicate acts are considered facts necessary to constitute a compound-complex

119. See supra notes $28-32$ and accompanying text.

120. See supra note 30.

121. 21 U.S.C. $\$ 844$ (a). Section 844 also contains recidivism provisions that increase the penalties for those who have already been convicted under state or federal narcotics laws. For instance, a defendant with two or more prior narcotics convictions would face a maximum of three years imprisonment, a fine of not less than $\$ 5000$, or both. Id.

122. Id. $\$ 960(\mathrm{~b})(1)(\mathrm{H})$ (1988 \& Supp. IV 1992). Section 960 , too, contains provisions increasing the penalties for repeat drug offenders. For instance, if an individual is convicted under $\$ 960$ after a prior drug felony conviction, he faces a maximum penalty of life imprisonment, a fine not to exceed $\$ 8,000,000$, or both. Id.

123. See supra text accompanying notes $60-63$.

124. United States v. Canino, 949 F.2d 928, 947 (7th Cir. 1991) (emphasis added), cert. denied., 112 S. Ct. 1940 (1992). 
offense for purposes of requiring jurors to find facts beyond a reasonable doubt, those same predicates should also constitute principal factual elements of the offense for the purpose of requiring specific unanimity under the Sixth Amendment. Therefore, according to the Schad dissent, the Constitution requires predicate acts to be treated as elements of the offense.

\section{Current Practice}

Only one part of the Schad due process analysis does not, at first glance, support a finding that the Constitution demands unanimity as to the predicate acts underlying a compound-complex conviction. In addition to historical practice, the Schad plurality looked to widely shared practice as an indication of what process is required by notions of fundamental fairness. ${ }^{125}$ Certainly, compound-complex statutes are widely used at the federal level and have often been copied in state criminal law. Nevertheless, as the plurality opinion admits, current practice is not dispositive in defining fundamental fairness. ${ }^{126}$ Indeed, neither history nor widespread acceptance may insulate a procedure from constitutional attack, and methods of defining criminal offenses are always open to critical examination. ${ }^{127}$

Compound-complex statutes seem ripe for re-examination. Although compound-complex statutes have been in use for twenty-five years, the Supreme Court first articulated due process constraints on verdict specificity in 1991. ${ }^{128}$ Since the Supreme Court decided Schad, only the Anderson court has considered whether predicate acts survive due process scrutiny if they are not considered elements of the offense. The split in the circuits over the status of CCE predicates makes the question even more pressing. Considering the disagreement apparent among Schad, Echeverri, Canino, and Anderson, current practice does not militate in favor of finding predicate acts to be mere means consistent with due process; rather, the current confusion surrounding the status of predicate acts demands insightful due process analysis.

Fifth Amendment due process demands that a jury unanimously agree upon the specific predicate acts that support a conviction under a federal compound-complex criminal statute. Predicate acts have no historical analogue, and alternate series or patterns of predicate acts likely reflect significantly different notions of blameworthiness or culpability. In addition, no cour considering predicate acts has held that each juror need not be convinced beyond a reasonable doubt of the predicate supporting his or her vote of guilty.

125. See supra text accompanying note 54 .

126. Schad v. Arizona, 501 U.S. 642 (1991) (Souter, J.. plurality opinion).

127. See id. at 642-43 (citing Pacific Mut. Life Ins. Co. v. Haslip. 499 U.S. I. 18 (1991)) ("IN]etther the antiquity of a practice nor the fact of steadfast legislative and judicial adherence to th through the centuries insulates it from constitutional attack.").

128. See supra par II.B. 
Therefore, the Schad plurality, concurrence, and dissent all support the conclusion that the Fifth Amendment demands specific unanimity as to predicate acts.

\section{PROTECTING DEFENDANTS' RIGHTS TO SPECIFIC UNANIMITY IN COMPOUND-COMPLEX CRIMES}

According to the foregoing analysis, the Fifth Amendment requires that predicate acts in compound-complex crimes be considered principal elements of the offense deserving specific juror unanimity. In order to give force to the Fifth Amendment's requirements, the Sixth Amendment requires the trial judge to issue to the jury a specific unanimity instruction whenever there is a genuine possibility that the jury will convict without unanimously agreeing upon the predicate acts supporting the verdict. This condition is per se fulfilled whenever the prosecution presents evidence of more than the requisite number of predicate acts. Further, in particularly complicated compound-complex trials, judges may want to guard defendants' rights through the use of special interrogatories. While special interrogatories are not required by the Sixth Amendment, trial judges have the discretion to employ them at the defendant's request.

Unanimity as to principal factual elements is enforced primarily through the mechanism of the judge's charge to the jury at the close of a criminal case. As a rule, "a general instruction on unanimity ... advising the jury that its members must unanimously agree on any aspect of the case as to which it renders a verdict... protects the defendant's right to a unanimous jury decision." 129 Even in a case in which the jury is presented with evidence of multiple counts or schemes, it may be possible to protect the defendant's right to a unanimous jury verdict through such a general instruction. ${ }^{130}$ When it appears, however, "that there is a genuine possibility of jury confusion or that a conviction may occur as the result of different jurors concluding that the defendant committed different acts," the Sixth Amendment requires the court to augment the general unanimity instruction with a specific unanimity instruction. ${ }^{131}$ The specific unanimity instruction should focus on the

129. United States v. North, 910 F.2d 843,876 (D.C. Cir. 1990).

130. United States v. Echeverry, 719 F.2d 974, 974 (9th Cir.), modifying 698 F.2d 375 (9th Cir. 1983).

131. Echeverry, 719 F.2d at 975 ; see also United States v. Echeverri, 854 F.2d 638, 643 (3d Cir. 1988) ("The usual rule that a general unanimity instruction is sufficient gives way "where the complexity of the case, or other factors, creates the potential that the jury will be confused." (quoting United States v. Beros, 833 F.2d 455, 460 (3d Cir. 1987))); United States v. Duncan, 850 F.2d 1104, 1114 (6th Cir. 1988) (holding that "[t]he touchstone [for issuing a specific unanimity instruction] has been the presence of a genuine risk that the jury is confused or that a conviction may occur as the result of different jurors concluding that a defendant committed different acts"). 
particular evidentiary conflict that may give rise to the confusion or the risk of a patchwork verdict. ${ }^{132}$

Without the use of special verdicts or special interrogatories, ${ }^{133}$ it is impossible to know which jurors are convinced beyond a reasonable doubt of which predicate acts. Therefore, if more than one eligible combination of predicates exists, there is, by definition, a genuine possibility that the jurors will come to a patchwork verdict of guilty. Indeed, the cour in Echeverri found the possibility for confusion to be "obvious" when evidence of many potential predicates was presented. ${ }^{134}$ Whenever the prosecution presents evidence of more than the requisite number of predicate acts, then the Sixth Amendment requires the judge to issue a specific unanimity instruction to protect the defendant's constitutional right to a unanimous verdict in a federal criminal trial.

The Sixth Amendment requires only a specific unanimity instruction to protect the defendant in a compound-complex criminal case. In most cases, this mechanism will adequately protect the defendant's rights. In certain particularly complicated compound-complex criminal trials, however, even a specific unanimity instruction may not sufficiently guard against jury confusion over predicate acts. Confusion is most likely to occur when the predicates are so intertwined as to make identification of specific acts difficult. When the prosecution presents evidence of many overlapping and intertwining predicate acts, the jury may have difficulty identifying the specific acts upon which it needs to agree. In addition, the judge may not be able to identify exactly which predicates support a conviction. In situations such as these, the only way to enforce and monitor specific unanimity is through departure from the general guilty verdict.

Civil law recognizes two types of particularized verdicts. The first is the special verdict, a procedure that requires the jury to answer questions about particular facts at issue rather than simply to render a general verdict as to guilt or innocence. The trial judge then determines the law, applies it to the facts found by the jury, and pronounces the defendant guilty or innocent. ${ }^{135}$ The second type of particularized verdict is the special interrogatory, which

132. For example, the defendant in Echeverri, 854 F.2d at 642. requested that the judge issue an instruction that read, "You must unanimously agree on which three acts constitute the continung senes of violations [under the CCE statute]."

133. See infra text accompanying notes $135-49$.

134. Echeverri, 854 F.2d at 643. After holding that CCE predicates are essential elements of the CCE offense and deserve unanimous agreement, the Echevern court determined that the Sixth Amendment required the judge to give the jury a specific unanimity instruction in Echeverri's case. The courn stated that "'where the complexity of the case, or other factors, creates the potential that the jury will be confused," id. (quoting United States v. Beros, 833 F.2d 455, 460 (3d Cir. 1987)), a specific unanimity instruction is warranted. Largely because there was evidence of numerous alleged predicate acts, any threc of which could have been the focus of a particular juror, the complexity and other factors were "obvious," and a specific instruction was warranted.

135. See Trubitt, supra note 26 , at 496 . 
requires the jury to return a traditional general verdict of guilt or innocence but also requires it to make several specific findings of fact. ${ }^{136}$

Traditionally, courts have been very reluctant to require anything but general verdicts in criminal cases. One of the main functions of the jury is to protect the criminal defendant from government oppression. ${ }^{137}$ The general verdict is perceived as an integral part of that protection; through the general verdict, the jurors are able to "blend[] law and fact, and ... follow[] the prejudices of their affections or passions."138 Thus, those opposing particularization of the jury's decision-making process contend that a jury is more likely to reach a verdict of guilty if forced to approach the decision step by step, instead of in its entirety. ${ }^{139}$

As a result of this deeply ingrained preference for general verdicts, it is widely agreed that special verdicts are improper in criminal cases. ${ }^{140}$ Fortunately, special verdicts are not necessary to preserve a defendant's right to a unanimous verdict in compound-complex criminal cases. There is no need to remove from the hands of the jury the ultimate application of law to fact, as the special verdict does. Any potential problems with patchwork verdicts stem from the difficulty jurors may have in determining whether or not they have unanimously agreed upon the requisite number of particular acts. Once this difficulty in fact-finding is resolved, the determination of guilt or innocence is relatively simple. All that is needed, then, is a mechanism through which the trial court and jury can be certain the jury was unanimous as to specific predicate acts on its way to reaching a general verdict of guilty.

136. See id. at 500 .

137. Brown v. Louisiana, 447 U.S. 330,330 (1979).

138. This poetic defense of the general verdict is attributed to Lord Mansfield in his Argument in the Dean of St. Asaph's Case. See United States v. Coonan, 839 F.2d 886, 896-97 (2d Cir. 1988) (Altimari, J., dissenting) (emphasis omitted). Indeed, many great jurists have defended the general verdict over the years. Learned Hand described the general verdict and the accompanying power of jury nullification as "tempering [the law's] rigor by the mollifying infuence of current ethical conventions." United States $e x$ rel. McCann v. Adams, 126 F.2d 774, 776 (2d Cir. 1942). Criticizing the use of special verdicts, Justice Holmes wrote that it is unwise to make the law more scientific if, in the process, it becomes less just. OLIVER WENDELL HOLMES, COLLECTED LEGAL PAPERS 237-38 (1920).

139. As the court in United States v. Spock, 416 F.2d 165 (1st Cir. 1969), wrote:

In the exercise of its functions not only must the jury be free from direct control in its verdict, but it must be free from judicial pressure, both contemporaneous and subsequent. . . . "It is one of the most essential features of the right of trial by jury that no jury should be compelled to find any but a general verdict in criminal cases, and the removal of this safeguard would violate its design and destroy its spirit." . . There is no easier way to reach, and perhaps force, a verdict of guilty than to approach it step by step. A juror wishing to acquit, may be formally catechized.

Id. at 181-82 (citations omitted).

140. Id. at 165; Trubitt, supra note 26, at 502 (collecting cases). But see Karen J. Ciupak, Notc, RICO and the Predicate Offenses: An Analysis of Double Jeopardy and Verdict Consistency Problems, 58 NoTRE DAME L. REV. 382, 407-08 (1982) (endorsing use of special verdicts in RICO cases in order to enable reviewing court to determine predicates upon which conviction was based); Harvey, supra noto 63, at 307-13 (recommending special verdicts to enforce "substantial majority" requirement as to CCE predicate acts). 
District courts do have the special interrogatory at their disposal. While the Federal Rules of Civil Procedure explicitly allow district courts to require a jury to respond to special interrogatories, ${ }^{141}$ the Federal Rules of Criminal Procedure contain no such grant of authority. However, Federal Rule of Criminal Procedure 57(b) provides that, in the absence of a procedure specified by the rules, the court may proceed "in any manner not inconsistent with these rules or those of the district in which they act." ${ }^{142}$ Case law on the subject makes clear that district courts have the discretion to utilize special interrogatories where the "risk of prejudice to the defendant is slight and the advantage of securing particularized fact-finding is substantial." ${ }^{1+3}$ In the alternative, a court of appeals may require the district courts under its supervision "to follow procedures deemed desirable from the viewpoint of sound judicial practice although in nowise commanded by statute or by the Constitution." ${ }^{144}$ This supervisory power covers jury instructions deemed advisable, though not constitutionally mandated. ${ }^{145}$ Therefore, it is in the district courts' discretion to use, and in the appeals courts' power to prescribe, the use of special interrogatories in particularly complicated compoundcomplex criminal trials.

Special interrogatories guard well the defendant's right to a unanimous verdict without compromising the defendant's right to a general verdict. In a compound-complex case, a special interrogatory would require the jurors to identify, through a multiple choice format, ${ }^{146}$ the specific predicate acts upon which they unanimously agree. In order to protect the defendant's right to a general verdict, only after a jury has voted to convict should the trial judge

141. FED. R. CIV. P. 49(b) states:

The court may submit to the jury, together with appropriate forms for a general verdict, written interrogatories upon one or more issues of fact the decision of which is necessary to a verdict. The cour shall give such explanation or instruction as may be necessary to enable the jury both to make answers to the interrogatories and to render a general verdich, and the court shall direet the jury both to make written answers and to render a general verdict.

142. FED. R. CRIM. P. 57(b); see also United States v. Ruggiero, 726 F.2d 913, 926 (2d Cir.) (Newman, J., concurring in part and dissenting in part), cert. denied sub nom. Rabito v. United Sustes, 469 U.S. 831 (1984).

143. Ruggiero, 726 F.2d at 927 (Newman. J., concurring in part and dissenung in part) In United States v. Ogando, 968 F.2d 146 (2d Cir. 1992), the court approved of special interrogatones in CCE cases. stating:

Despite our stated preference for special interrogatories in paricularly complex cnmınal cases, we have declined to delineate bright-line rules for determining when such interrogatories should be employed or in what form. ... Rather, we commit the decision of whether and how to Id. at 149. utilize special interrogatories in such cases to the broad discretion of the district court.

144. Cupp v. Naughten, 414 U.S. 141, 146 (1973).

145. United States v. Rubio-Villareal, 967 F.2d 294. 297 (9th Cir. 1992).

146. Requiring jurors to produce, on their own, a list of the predicale acts on which they agree would saddle them with the burden of delineating and accurately describing each of the predicate acts upon which evidence was presented. This would weight the use of special interrogatories too much in favor of the criminal defendant. If the court presents the jury with a list of all eligible predicates upon which the prosecution presented evidence, the defendant's rights are protected without unduly prejudicing the prosecution. 
inform the jury of the interrogatories and instruct it to answer them. This should alleviate the concern that the use of the special interrogatory will lead an otherwise merciful jury to convict. ${ }^{147}$ Further, judges should employ special interrogatories only at the request of the defendant. ${ }^{148}$ Since any prejudice of special interrogatories generally runs against the defendant in a criminal trial, ${ }^{149}$ it is difficult to understand how either judges or prosecutors could object to a defendant's request for this form of particularized factfinding. Therefore, in particularly complicated compound-complex criminal trials, district courts should, upon a defendant's request, utilize special interrogatories in order to protect criminal defendants' rights to specific unanimity as to predicate acts underlying a guilty verdict.

\section{CONCLUSION}

Compound-complex crimes create new challenges for judges confronted with problems of verdict specificity. By defining criminal activity through the use of predicate offenses, these statutes strain common notions of crime and its elements and raise the question of whether jurors must unanimously agree on the specific predicates underlying their verdict. The Sixth Amendment requires jurors to agree unanimously as to the principal factual elements of an offense but begs the central question of what constitutes a principal factual element. Only through reference to Fifth Amendment due process constraints can we create a constitutional framework through which to analyze verdict specificity in compound-complex crimes. Indeed, this constitutional framework demands that a convicting jury unanimously agree upon the predicates supporting a guilty verdict. In order to protect defendants' rights, trial judges are constitutionally required to issue a specific unanimity charge whenever the prosecution presents evidence of more than the requisite number of predicate acts. In most cases, this instruction will adequately protect defendants' rights under both the Fifth and Sixth Amendments. However, in particularly complicated compound-complex criminal cases, and then only upon the requests of defendants, judges should utilize special interrogatories to further

147. See Ruggiero, 726 F.2d at 928 (Newman, J., concurring in part and dissenting in part) (recommending interrogatories in RICO case to ensure unanimity as to predicate acts); Robert M. Grass, Note, Bifurcated Jury Deliberations in Criminal RICO Trials, 57 FORDHAM L. REv. 745, 753-54 (1989) (describing potential use of special interrogatories in RICO cases).

148. Although doctrinally it makes no difference whether the defendant requests the special interrogatories before or after the jury has returned its verdict, the district courts should, for ease of administration, require the defendant to request the interrogatories before the judge issues her specific unanimity instruction and submits the case to the jury. In civil cases, "[t]he district judge's decision to use interrogatories along with a general verdict, and which interrogatories to submit, ordinarily should bo made before the case is submitted to a jury so that the parties can react to the court's decision." 9A CHARLES A. WRIGHT \& ARTHUR R. MILIER, FEDERAL PRACTICE AND PROCEDURE § 2512 (1995) (citing Scarborough v. Atlantic Coast Line R.R., 190 F.2d 935 (4th Cir. 1951)). This rationale applies equally well in the context of a criminal case.

149. See supra text accompanying notes 137-139. 
protect the defendants' rights to a unanimous jury verdict. Only through these mechanisms can federal trial judges, like Daniel, avoid "passing unjust sentences" and "condemning the innocent." 
